\title{
Erosion Zoning of the Territory of the Chechen Republic as a Basis for Sustainable Development
}

\author{
Idris Bayrakov \\ Chechen State University, 32, A. Sheripov Str., 364907, Grozny, Russia
}

doi: https://doi.org/10.21467/abstracts.93.29

\begin{abstract}
A B S T RA CT
Sustainable development of territories is a dynamically developing process of transition to a new, highquality level of environmental management, aimed at ensuring environmentally balanced development. The territory of the Chechen Republic is subject to erosion processes, in its parts erosion processes provoke the active development of desertification processes. The erosion zoning of the territory should be taken as the basis for the further development of erosion control measures and the prospective development of agriculture. Agricultural production in the republic is mainly concentrated in five erosion areas, where only about 80 percent of all farm lands are intensively used.

A soil-erosion survey indicates that 599 thousand hectares of agricultural land in the republic are potentially dangerous erosion, and 320.9 thousand hectares are affected. Erosion affects 23.8 percent of arable land, 53.8 percent of hayfields and 64 percent of pastures. Eroded arable land must be tinned with perennial herbs and used for haying. On forage lands, afforestation of 4 thousand hectares is necessary, terracing of steep slopes - by 2.7 thousand hectares, a radical improvement of 48.2 thousand hectares of pastures, exclusion from pasture rotation for 3-4 years of 21.3 thousand hectares. Geobotanical and agroecological survey showed that surface improved pastures should be carried out on an area of 527 thousand hectares. In the semi-desert zone, cooling of the hollows of blowing was provided, followed by fixing the sands with perennial grasses. In each separate zone there are special soil-protective crop rotations that will contribute to the formation of a closed vegetation cover, a reliable means of protection from the destruction of the soil surface by wind forces. Erosion zoning of Chechnya was made on the basis of the study, systematization and analysis of all materials of soil-erosion and geological surveys, taking into account natural and climatic conditions. Several erosion areas have been identified:
\end{abstract}

$>$ Strong wind erosion;

$>$ Average wind erosion;

$>$ Weak wind erosion;

$>$ Strong water erosion;

$>$ Average water erosion;

$>$ Weak water erosion.

In areas of intense manifestation of wind erosion in crop protection rotations, long-term grasses are recommended. In total, in the republic, taking into account the topography and the degree of soil erosion, 52.8 thousand hectares of arable land are allocated for soil protection crop rotation. Taking into account the nature and intensity of the manifestation of erosion processes for each eroded area, it is necessary to develop a set of agrotechnical measures, which provides for soil cultivation that increases its water absorption capacity, resistance to washing off, erosion and blowing by the wind; soil protection from erosion with the help of vegetative cover; moisture accumulation and conservation; the use of organic and mineral fertilizers.

(C) 2020 Copyright held by the author(s). Published by AIJR Publisher in "Abstracts of The Second Eurasian RISK-2020 Conference and Symposium” April 12- 19, 2020, Tbilisi, Georgia. Jointly organized by AMIR Technical Services LLC, Georgian Technical University, Institute of Geography (Kazakhstan) and Russian Institute of Petroleum Geology and Geophysics.

AijR DOI: $10.21467 /$ abstracts.93 
The Second Eurasian RISK-2020 Conference and Symposium

Soils under the plant cover and its remains, deflation, washout and erosion are almost not exposed. These protective properties of the vegetation cover are the basis for the planned agrotechnical measures.

In the semi-desert zone, depending on the mechanical composition of soils, the following agrotechnical methods are proposed:

$>$ minimization of pre-sowing soil treatment;

$>$ radical and superficial land improvement;

$>$ rational use of pastures (hayfields - pasture rotation, normalized grazing);

$>$ strip placement of crops;

$>$ subsurface tillage with flat cutting tools;

$>$ stubble sowing;

$>$ backyard crops;

$>$ cross sowing.

The scale of manifestation of erosion processes on the territory of the republic is huge, as well as the consequences - the decline in soil fertility and the quality of land resources stimulated the scientific community of the republic to develop and implement a general scheme of scientifically based anti-erosion measures, which formed the basis of the program for optimizing the environment. 